\title{
Is Motherhood Compatible with Political Participation? Sophie de Grouchy's Care-Based Republicanism
}

\author{
Sandrine Berges
}

Accepted: 12 March 2014

(C) Springer Science+Business Media Dordrecht 2014

\begin{abstract}
Motherhood, as it is practiced, constitutes an obstacle to gender equality in political participation. Several options are available as a potential solution to this problem. One is to advice women not to become mothers, or if they do, to devote less time and energy to caring for their children. However this will have negative repercussions for those who need to be cared for, whether children, sick people or the elderly. A second solution is to reject the view that political participation is an important or necessary part of human flourishing, and allow that those who engage in caring activities can live good lives without having a say in how they are ruled. This has negative consequences for the carers who find themselves in a position, if not of direct oppression, of being dominated, and therefore susceptible of being oppressed. The solution I propose, inspired by the writings of Sophie de Grouchy, is that we look for a form of republicanism that regards caring activities as a form of political participation.
\end{abstract}

Keywords Caring · Political participation $\cdot$ Republicanism $\cdot$ Feminism $\cdot$ Sophie de Grouchy

The great revolution that has not happened is a revolution in shared responsibility for the family, in child care and in child rearing. Until those happen, you will not see more than a very small number of women, in my view, opting for a job as demanding as politics. ${ }^{1}$

\section{The Apparent Incompatibility Between Political Participation and Caring}

Many of us are familiar with the pictures of Member of European Parliament Licia Ronzulli bringing her newborn daughter to vote at European court first as a newborn, and later, as a

\footnotetext{
${ }^{1}$ Shirley Williams in Holtzman and Williams $(1987,30)$. This is cited by Susan Moller Okin in the introduction to her 1989 Justice, Gender, and the Family. Okin also argues that political inequality is caused in great part by the unequal distribution of family responsibilities.

Many thanks to Bill Wringe, and Eric Schliesser for feedback on early drafts of this paper, and to Axel Gosseries, Philippe Van Parijs and those present at the 'Mardi intime de la chaire Hoover' in April 2013, where I presented a version of this paper for their insightful questions and comments. This paper also benefited from valuable comments by two anonymous referees.
}

S. Berges $(\bowtie)$

Department of Philosophy, Bilkent University, Bilkent, 06800 Ankara, Turkey

e-mail: sandrineberges@gmail.com 
toddler. We're familiar with them, because they made the news all over the world: it is that unusual to see children around working politicians - unless we count politicians kissing babies they don't know as a publicity stunt. The thought is that to be a politician, one needs to sacrifice one's private life for the benefit of the people one has agreed to serve. A political career involves working long hours which often conflict with children's schedules, so that a politician who wants a home, or children, must also have a partner who is able to take care of them. ${ }^{2}$ This usually means a wife, in the sense of somebody who can provide the home life and stability judged necessary for bringing up children, somebody who is able to put in twice the work (their own and their partners) to ensure that the children's needs are satisfied. Men are sometimes seen to fulfill that role, when children are older, so that their wives can pursue more demanding careers. But most of the time, it is still expected that women will be around to care for their newborn, that if they don't they're not being good mothers. This seems to preclude any kind of political career-hence the shock of the Licia Ronzulli pictures.

My initial hypothesis is thus that motherhood as it is practiced is an obstacle to the political participation of women. Being a mother is hard to reconcile with a political career, and this is one of the reasons why there are so few women in politics. That there are few women in politics is not hard to establish. The 2013 gender gap report shows that even for countries in which there is no measurable inequality in the education of boys and girls, the political participation is far from equal. ${ }^{3}$

The issue of participation is complicated by the different ways in which one can understand political participation. At the lowest level, to participate is to be able to vote, that is, to have the right to vote, to be in a position to go to the urns on voting days, and to have access to documents that will inform our choice. On the other end of the scale is the most active part of participation, that is, participation in government. In between, one can participate by belonging to a political party, joining in demonstrations, writing, distributing, or simply signing petitions, writing to one's representative, etc. In most parts of the world, women can in principle participate in the first sense, but nowhere is the level of participation in the most active sense truly equal between men and women. ${ }^{4}$ The Inter-parliamentary Union data drawn from national parliaments data for 189 countries on 1 April 2013 tells us that only three countries approximate gender equality in lower parliament: Rwanda, Andorra and Cuba. The top European countries in the table are Sweden (44\%), Finland, Iceland and Norway (38\%). France manages just below $27 \%$ and the UK just over $22 \%$, with the US at less than $18 \%$ and Turkey at just over $14 \%$. Yemen, with one woman in parliament gets $0.3 \%$. $^{5}$ These are dire figures. Women are nowhere near equally represented in parliaments and so do not participate in public life on an equal basis.

\footnotetext{
${ }^{2}$ See Van der Dussen (2012) who argues that what is particularly demanding about a political career is the fact that political time-tables and timing conflict with family time-tables and timing on several levels, so that it is harder to make the two work together than it would be for a different sort of career.

${ }^{3}$ Hausmann et al. (2012), pp. 9, 10, 15, 16.

${ }^{4}$ According to the Global Gender Gap report for 2013, the highest scoring countries in political empowerment, recording the female/male ratio of seats in parliament, ministers and number years as ruler (over the last 50 years) is Iceland, with a score of 0.7325 , or roughly two women for every three men, with Norway in the third position falling to 0.5616 , that is, close to one woman for two men. Germany ranks 15, with one woman for three men, and countries ranking from 87 to 133 (Estonia to Saudi Arabia) have a score of less than 0.1. Interestingly, low levels of political empowerment do not necessarily correspond to an overall wide gender gap. Two of the lowest ranking states as far as empowerment is concerned-Bahamas, 122, and Bostwana, 124 - have high scores in educational attainment (both score 1.0000, equality) and economic participation, 37 for Bahamas, with a score of 0.8359 , and 77 for Bostwana, with a score of 0.7076 .

5 http://www.ipu.org/wmn-e/classif.htm accessed 24/09/2013.
} 
The low level of female participation in government has serious impact for democracy. It is hard to imagine that with such low levels of active female participation in politics worldwide, women voters are going to be properly represented. Again, this can be taken to mean several things, one that they are not physically represented, that there isn't a proportion of women politicians equal to the proportion of women voters, and secondly, that women's interests are not represented, which is often a consequence of a lack of physical representation, but is not always solved by adding to physical representation: the fact that women in parliament are a minority often means that they adopt coping strategies that involves acting and thinking as their male counterparts do. ${ }^{6}$ When women are not represented, in the second sense, i.e. when they feel that political agendas have little to do with their lives, they are in turn less likely to want to participate at the most basic level - why vote to choose between two men who know nothing of our difficulties and do not care to find out? So participation, at various levels, affects and is affected by representation at various levels.

If motherhood - either as a fact, i.e. being currently responsible for infants of young children, or as a possibility, having been brought up to prepare for this, or even as an external expectation, being perceived by others as potential mothers and hence not as suitable for a political career - is at all responsible for this radical gender disparity, then, as a feminist, one might be tempted to advise women against motherhood, and to reject the close links that society has created between caring and women. One, rather extreme, way of putting this would be to say that caring for a baby is simply a form of work, one that most people do not find particularly interesting, that parents are willing to do because they believe the children to be their responsibility, but that they would gladly leave to paid professionals if they could. That the duty to care for baby is particularly a mother's duty is emphasized by societies in which groups (governments, private employers) or individuals (fathers) wish to avoid being made to share in that responsibility. This is not to deny that many individuals - men and womenactually enjoy some aspects of caring for infants, but that it is by no means a universal trait, any more than it is true that most people would enjoy teaching, farming, being a surgeon, or other professional activities which are necessary for the well-being of all. Many women do enjoy parenting, and regard it as one of the most valuable aspect of their lives, but it is nonetheless a job that any adult can perform, and it's not fair to expect women to do most of it. While things are slowly changing in some countries, and men are offered the opportunity to take parental leave and do actually take it, it is not the case in most parts of the world that the general public of businesses regard it as normal for men to give up work in order to care for children. In fact, despite ongoing reforms in several countries, men who would prefer to take equal responsibility for parenting are not, on the whole, in a position to do so.

The obstacles to a good caring experience from the parents' point of view appear to be coming not from qualities intrinsic to caring itself, but from the difficulties thrown in parents' ways by a social arrangement that devalues parenting. It is only natural that some of those who value their professional life would, under such circumstances, come to regard parenting duties as a nuisance. But treating parenting as a necessary, but not particularly interesting job won't get us very far. Babies have to be cared for, as do sick people and the elderly, and they have to be cared for willingly, and lovingly. Denigrating this work will only mean that even less people are willing to do it, when clearly, it requires a lot of practitioners - we need more carers than we need farmers, bakers, mechanics and mathematicians. The alternative is to focus on the positive, find out what may be valuable about caring such that people would want to do it and be valued for their work. It is in order to re-instate care as a valuable practice that care-ethicists are proposing that we consider that caring should be central to moral theory, not simply

\footnotetext{
${ }^{6}$ The Participation of Young Women in Political Life, Final Report, Council of Europe 2002, p.8.
} 
something women are expected to do, but something that needs to be done, that matters, and that is morally, as well as personally valuable. ${ }^{7}$ Caring is not an annoying necessity, but a moral necessity, one that defines who we are. Someone who is denied the opportunity to spend a portion of their lives engaging in caring activities, is just as badly off as someone who is denied the opportunity to work, or to engage in political activities.

There are two ways we can go from such a conclusion. One is to decide that because care is valuable, men, as well as women should be encouraged to engage in it, and the other is carry on as before, with women doing most of the work of caring, but making sure that they are appropriately valued and rewarded for their work. On the second model, there is still little room for women to take active part in politics. No matter how well paid they are, women who are responsible for bringing up children will almost certainly find that this conflicts with active political participation. Furthermore, on this model, men are denied the opportunity to participate in caring activities and this is potentially just as harmful for them as preventing women from engaging in political activities.

When I discussed the conflict between caring and political participation at a seminar in political philosophy, the consensus was that there was a clear and simple solution: shared care. Given that it generally takes two people to produce a child, if each parent takes equal responsibility for the child's care, then there is no longer a gender unbalance in the home. This will eventually lead to a better political balance: sure, parenting will still make having a political career difficult, but it won't be a problem just for women, and it will be, if not a problem halved (childcare problems not being typically amenable to simple arithmetic) at least a problem reduced. A further consequence will be a greater awareness of the challenges of parenting, which will eventually result in a better infrastructure enabling parents to combine work and childcare without ever having to 'sneak out'. Being able to discuss openly the trouble we have getting to work on time when the children have to be gotten ready and to school, or having to leave a meeting because it's time to pick them up, will surely improve the general atmosphere for working parents.

One obvious objection to this simple solution is that it is difficult to see how this will help single parents, who, even if they are in touch with the second parent, and attempting to coparent, will obviously not have the sharing capacities two parents families have. Half of single parents families in the UK had their children within marriage and divorced later. However, divorced parents may move away, form new families, which will make it harder to share fully in the upbringing of their first children. This is not an exceptional problem: in the UK, for instance, single parent families make up a quarter of all families, and most heads of single families households are women ( $8 \%$ are men). ${ }^{8} 9$

But even in two parent families, it is far from obvious that shared care is a simple and straightforward solution. The audience of the seminar who reacted in this way to the problem I presented them with were all academics, i.e. people who tend to believe in gender equality, do not easily accept stereotypes of any kind and are not afraid of being radical. One would expect academics to be more aware of gender issue than some other parts of the population, and one would expect them to act on this awareness. Yet, there is very little gender equality in

\footnotetext{
${ }^{7}$ Nel Noddings (2002:1) describes care ethics as a reversal of Plato's or Aristotle's ethics. Instead of starting from a description of the polis and drawing conclusions for the lives and characters of individuals, we start from the home and draw conclusions for the good running of society.

${ }^{8} \mathrm{http} / / /$ www.gingerbread.org.uk/content/365/Statistics, accessed 24/09/2013.

${ }^{9}$ A further worry is that shared-care would mean that politics were left to non-parents, i.e. the very young, and those who choose not to have children. This would make for just as skewed a political world as one in which there are no women, and politicians would find it very hard to address the concerns of parents. I owe this point to an anonymous referee.
} 
academia, and philosophy, especially, is very gender unequal. In a 2011 update on a report to the APA committee on the status of women, Kathryn Norlock tells us

Roughly, among full-time instructional faculty, women are $16.6 \%$ of the 13,000 total full-time philosophy faculty (that is, 2,158), and $26 \%$ of the 10,000 part-time instructors (that is, 2,600). In other words, women are 4,758 of the 23,000 or so: $20.69 \%{ }^{10}$

This is born out in publication records: between 1991 and 2012, only $12.1 \%$ of authors of philosophical publications were women, compared to $46.6 \%$ in education, $29.3 \%$ in classical studies and $18.3 \%$ in probability and statistics. ${ }^{11}$ Moreover, it seems that it is not the case that women don't choose to enter the field in the first place, but that they drop out. In a paper for Hypatia, Paxton et al. show that there is a steady decline from the first year of undergraduate study to the full professor level (2012).

Given that women make up a significantly larger proportion of part-time faculty than they do of full time faculty, and given that within full-time faculty they have less access to the top of the profession (only $17 \%$ of US full philosophy professors are women), it is clear that at least more women want to become academic philosophers than have a successful career at it. So what makes it so hard for women to participate fully in academic philosophy? Is academic philosophy at all like politics in the time constraints under which it operate? True, some aspects of a philosopher's agenda are unpredictable: we go to conferences, engage in funded research projects which necessitate visits to other institutions, and some of our publishing deadlines are beyond our control (e.g., revise and resubmit). Also, philosophers sometimes have nonnegotiable early starts (8.40 classes) and late finishes (meetings held in the evenings or late afternoons). Some important professional contacts happen after hours, when philosophers take their visiting speakers to the bar after a seminar, and there is some weekend and evening work either around grading time, or to finish off important research.

None of the above are particularly avoidable - it would be easy to arrange for meetings to happen within normal working hours, and to make sure that faculty who cannot go out in the evening has the chance to see speakers informally during the day-take them out to lunch, or for coffee. It would not be difficult either to make it a priority to assign child-friendly teaching schedules to parents. In other words, although the time constraints academic philosophers are under look similar to that of politicians, it seems that there is no actual pressure to maintain these structures. If the academic time-tabling is not family friendly, it is only because those who are privileged in the professions, i.e. white, older men, prefer to keep it that way.

Shared care is not an obvious nor an easy solution: otherwise, those who would be most likely to take it up, because of their political inclinations, relative financial ease and with some leverage as to how they distribute their professional activities during the working week, i.e. academics, would be in a position to model this sort of arrangements to the rest of the world. Yet, very clearly, they don't. It's much harder for a mother than it is for a father to have a successful academic career. And given that voluntary shared care does not work out as a solution to gender equality in academia, it is unlikely that it would have much success as far as politics was concerned. ${ }^{12}$

\footnotetext{
${ }^{10}$ These are US figures taken from The APA Committee on the Status of Women: http://www.apaonlinecsw.org/ workshops-and-summer-institutes, accessed 24/09/2013.

${ }^{11} \mathrm{http} / / /$ flowingdata.com/2013/01/07/women-as-academic-authors-over-the-years/, accessed 24/09/2013.

12 This discussion may seem unfair to academic couples, who have the opportunity to share child-care equally. Though I can testify that some indeed do that, the fact that the majority of part-time academic faculties are women suggests that academic women still take more time off work than their male counterparts.
} 


\section{The Origins of Sympathy_A Care-Based Republicanism}

One response to the observation that those who care are not in a position to participate in politics is to move away from models which make political participation essential to the good life. This is partly what accounts for the feminist rejection of certain republican models. Those models, in particular those defended in the classical period and again in the eighteenth century, regard political participation as central to virtue - for Aristotle, as for Wollstonecraft, to be fully virtuous one must be a citizen. But if women are in practice excluded from active participation, then they cannot be valued, and they cannot flourish. ${ }^{13}$ Better to pick instead a model that values relationships over the acts of individuals, better to shift the focus of virtue and happiness to the home and away from the public domain. This is not to say that political participation is not to be considered a good, but that it is not essential to the good life, that it should be possible for half of humanity to flourish without participating in politics, but instead by engaging in caring work. Caring is to be regarded as equally rewarding, and equally conducive to a good life. Concepts derived from our idea of the good life, i.e. moral concepts, should then be accordingly modified to account for this different but equally valid life style. ${ }^{14}$

Even though it is undoubtedly good to raise the profile of caring, and make it as valuable as political participation, doing so without attempting to argue that both can be accommodated within one person's life raises the following worry. If half of humanity have no say over who rules them or how, then it becomes easy for the other half to oppress them. This is exactly the sort of worry Wollstonecraft voice when she demanded that women should not only be considered full citizens but that they should be given the means of achieving financial independence. Even a woman who is not oppressed by her husband, she pointed out, is not in a position to flourish as long as she has no political standing of her own and no way of achieving material independence (1992: 221-2, 226-7). A woman who is not an independent political being, but exists only in the home, as part of a marriage, or a family cannot become virtuous, and therefore, has no chance of being a good carer. Being a carer requires some sort of autonomy, and so cutting carers off from the public domain is not a solution.

For this reason, I propose that we not dismiss republican models without first taking a good look at them in order to decide whether they might be made to co-exist with the imperatives of care. What I would like to do in this section is show a way in which we can hold that both caring and participating are intrinsically valuable, but that their value is not separate from each other, i.e. that it is not desirable to exclude carers from participation, nor to participate without caring. Of course, a political model such as Aristotle's is going to be hard to modify to take into account the fact that women are also citizens. But the models developed during the enlightenment period are a lot more promising. The enlightenment was marked by the thought that sympathy, the propensity to feel for others, was the basis of moral thinking, and therefore, to be taken seriously when it came to social reform. ${ }^{15}$ One of the writers who defended a sympathy based social reform, and who has been marginalized - to the extent that she is now practically unknown - is Sophie de Grouchy. In what follows I show how she develops a

\footnotetext{
$\overline{13}$ See Philips (2000), Costa (2012) and Pateman (2007).

${ }^{14}$ This take on the problem, i.e. attributing value both to caring and to political participation, but claiming that one can do one or the other but not both, is a form of difference feminism if one claims that caring is best for women and participation for men. However, it strikes me that one could hold the view that caring and participation are both goods and that one must choose between them, is not tied to gender difference: Michael Slote (2011) seems to hold the view that many values are partial (including family and career), so cannot be sought at the same time, does not claim that women are any more predisposed then men to choose family over career.

${ }^{15}$ See Nussbaum (1996), esp. 30-31.
} 
republican proposal for social reform which takes caring relationships, and in particular mothering, as central. I argue in a final section that her views have implications for the way in which the work of caring for infants childcare and parental leave should be organized.

Adam Smith is the name which first comes to mind when we talk of sympathy. His Theory of Moral Sentiments, traces the principles of morality to sympathy, a natural distaste for other's suffering, which moves us not to cause it if we can help it. The text I focus on is Sophie de Grouchy's reaction to Smith's theory, her Lettres sur la sympathie written in 1792 and published as an appendix to her 1798 translation of the Theory of Moral Sentiments. ${ }^{1617}$

In the first of eight letters, De Grouchy explains that what prompted her to write this commentary was the observation that Smith merely observed the existence of sympathy and of its 'principle effects' but did not attempt to find its origins, even though their discovery is bound to affect our understanding not only of its effects, but of its development and preservation. $^{18}$

In the second and third letters, de Grouchy gives a detailed account of how sympathy comes into being, which puts her into a position to give an equally detailed account of how sympathy can be nurtured through education and the creation of good laws and institutions, in the fourth letter. In letters Five, Six and Seven, she gives the details of a moral theory based on sympathy, and in the final letter, she reiterates the social implications of her claims, namely that human flourishing requires sensible laws and institutions and the lack of excessive social inequalities.

Unlike Smith, who sees the sentiment of sympathy as a first principle, De Grouchy wants to trace it to a physiological first cause, that of the experience of physical pain and pleasure. ${ }^{19}$ Pain and pleasure, she says, produce two kinds of effects in our bodies, one that is local, focused on the part of the body that is injured or pleasured, and one that is general, a feeling of well-being or discomfort that affects our entire bodies. This general feeling, can be reproduced through remembering pain or pleasure, reflecting on it, or witnessing it in others. It is the latter, i.e. the experience of a general feeling of pain or pleasure upon witnessing someone else's pain or pleasure, that she calls sympathy. Sympathy is therefore first directed towards physical pain, and from there it reaches out to moral suffering. Also, because it is first experienced as a result of feeling the repercussions of a particular person's pain in one's body, sympathy is at first directed at particular individuals. Only later, through the development of our faculties, in particular the mastery of abstraction, does it extend to the general condition of a class of people, or even the whole of humanity; only then does it become moral thinking. Because it means at first the we feel specific individuals' pains and pleasures as our own, sympathy necessitates a sort of dependence between people. De Grouchy represents co-dependence as a fact of life, a necessity, which we all experience first hand as newborns, and then more or less, depending on our circumstances, throughout our lives. For de Grouchy, sympathy originates in the cradle, in the first relationship a human being is part of, that is, between a baby and its nurse. This first relationship not only teaches us to create a link between ourselves and other

\footnotetext{
${ }^{16}$ All references are to Brown and McClellan III 2008.

${ }^{17}$ Dawson (1991) argues that for Smith, sympathy is the basis of all human interaction, but that de Grouchy sees it especially as the basis of social reform. This makes the Letters on Sympathy especially relevant to care ethics, see Noddings (2002) 22.

${ }^{18}$ Brown, McClellan, 108. There is a question as to whether De Grouchy misunderstood Smith's point, i.e. interpreted his desire to use sympathy as a theoretical starting point as the belief that its origins could not be found. However, the conclusions De Grouchy draws from her own discussion of the origins of sympathy are interesting enough that we can suppose that she in fact had reason to disagree with Smith that it was enough to start from sympathy without delving further into its genesis.

${ }^{19}$ This is the source of two disagreements with Smith. First, de Grouchy disagrees with Smith that we feel less sympathy for physical pain than we do for moral pain, and secondly, that we feel little sympathy for pleasure. (letter 4).
} 
people, but to use this link in order to understand how they feel. It is also, she says, the first means by which we learn and develop:

The specific dependency on some individuals begins in the crib. It is the first tie that attaches us to our fellows. It causes the first smiles, and the most regular smiles of a child are for his wet-nurse; he cries when he is not in her arms and for a long time he loves to throw himself upon this breast that satisfied his first needs, that made him feel the first sensations of pleasures, and where at long last he began to mature and to form his initial life habits. ${ }^{20}$

Because we are dependent on our nurse, she goes on to say, the thought that she might suffer is bound to affect us more than somebody else's suffering would. We feel the connection between her life and ours, and we are more alert to what affects her. Later in life, she carries on, we develop individual sympathies for two kinds of people: those who can help us when we are in need, and those who share pleasures or interests with us. Again, there must be a link between these people and ourselves, in order for us to be able to experience their suffering as our own. The ability to form such links is learnt during our infancy and our survival and happiness later on depends on it. Individual sympathy, she argues, is also the basis for love and friendship. The link between two individuals who love each other must be strong enough that they are able to enjoy each other's happiness fully. She describes this link as a magnified interest for another, which makes us especially aware of what they feel in a way that is strongly reminiscent of some characterizations of caring, for instance Nel Noddings who writes that in caring relationships, the carer is 'engrossed' in the cared-for, that she 'feels' the cared-for feelings, even though she is aware that she may not have these feelings herself if she were in the same situation (Noddings 2002, 14-15).

\section{Educating Sympathy and Preserving it Through Sensible Laws: A Republican Ideal}

One thing that enlightenment or republican thinkers of that period have in common is that they all believe that education is crucial not only to personal development, but to the good organization of society. De Grouchy, like her contemporary Wollstonecraft, is a follower of Rousseau who argues that we must educate children from infancy, to help the right development of their natural inclinations to be good. For De Grouchy, this includes sympathy. ${ }^{21}$ In order to become more sympathetic, she says, we must become better at recognizing pain. This does not entail, of course, that parents should inflict pain on their children (though she does say that those who live harder lives tend to be more sympathetic than those who know only ease and pleasure). The role of parents and teachers is to familiarize children with suffering and develop their ability to recognize its symptoms. ${ }^{22}$ Also, in order to learn to move from individual to general sympathy, children must be taught abstraction. But education as it is practiced in eighteenth century France, she remarks, simply does not encourage abstract thinking. Learning by rote things one does not understand, and only touching on the very basics scientific pursuits will not do.

\footnotetext{
${ }^{20}$ Brown, McClellan, 117-8. Note that de Grouchy accepts the then common practice of wet-nursing, so that although the first relationship involves maternal practice, or mothering, to use Ruddick's terminology (1989 pp 17 and 51), it does not have to involve a child's biological mother, and could, in the 21 st century, involve a father.

${ }^{21}$ On how Wollstonecraft's theory of education drew on republican ideals see Berges (2013), 30-35.

22 She cites her own experience of visiting the poor with her mother as a crucial part of her own education. Brown, McClelland, 112.
} 
Educational reform is needed, in content as well as method. Here again her position is very close to Wollstonecraft's who bemoans the fact that girls, in particular, are not taught to think abstractly, and who also believes that the capacity for thinking beyond one's immediate circle is necessary for ethical thinking. ${ }^{23}$ Just as she believes in education's power to help human beings to make the most of their natural sympathy, de Grouchy shares many of her contemporaries' belief in the influence of laws and social institutions on human character. In fact, like Rousseau, she believes that this influence is preserving rather than shaping human character. She believes that we are naturally prone to sympathy and to developing moral beliefs based on this natural propensity, but that the most likely effect a law of institution will have is a perverting one. Therefore, the point of social reform is to ensure that laws and institutions do not actively prevent the natural development of human sympathy.

This is not to say that de Grouchy's views about social reform are in any way light-weight. She perceives the laws and institutions in their current state as extremely harmful to the proper development of human morality. A few years into the revolution has not undone the fundamental social and economic inequalities that crippled her country. And one could argue that in very few parts of the world has this been achieved today. In fact, the example she gives of how social inequalities work against sympathy is one that would not be anachronistic a century later: that of the relationship between a powerful boss and his employee. The social distance between them means that they will not recognize each other as someone who can experience pain as they do, and they will not feel sympathy for each other. As a result, the boss, she says, will oppress his employee without any remorse, and the employee will not think twice before cheating his boss. Virtues, she says, need to be placed at more or less the same height if they are to find each other. So at the very least, laws and social institutions should not separate people from each other, at least not to the extent that they do not recognize human virtues in each other and are unable to feel sympathy for each other. ${ }^{24}$

More than this, de Grouchy feels that reform is needed to undo the damage created by previous bad laws and institutions. If sensible laws and non-dividing institutions would in principle suffice to ensure that human beings develop as they are supposed to, given how much harm has been done and how divided the people she sees around her are, much more work is needed. And there is no suggestion that such reform could be gentle either, as 'vicious institutions' have not only corrupted our nature, but driven us to 'idiotic blindness' which makes us 'accept as a law of necessity the chains one has become incapable of judging or breaking' (175).

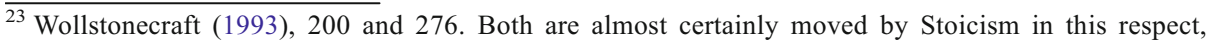
and the idea that the good stoic is a cosmopolite, one who owes his or her allegiance to humanity at large, not simply to family and friends. De Grouchy who had read Marcus Aurelius as a young woman would have been especially familiar with that idea, and with the accompanying thought that to achieve such moral heights necessitated an intellectual effort. Clearly, though, de Grouchy did not completely embrace this stoic ideal-for her, sympathy is never just an abstraction, and it is never the case that physical pain, in particular, matters less than moral pain, which, if she were a proper stoic, she would have to believe.

${ }^{24}$ On this De Grouchy disagrees with Smith who thinks that not only can we feel sympathy for a king, but we feel more for a king than we do for an equal because of their greatness. De Grouchy points out that if we do feel sorry for a fallen king, it is because we assume that their previous state did not do enough to prepare them for their current pain, but that on the whole, their being so much above us grates against our natural sense of equality, and disposes us to jealousy rather than sympathy.
} 


\section{Nursing and Participation ${ }^{25}$}

The feminist objection to republicanism we started with is that women have little or no place in an ideal that promotes public participation and individualism over care and relationships. We saw how, on de Grouchy's account, women's place in a society that valued relationships would be very central: mothering, or wet-nursing, forms the very basis of the way we are linked to each other, and able to flourish as members of a group.

In her picture, those who care for infants take centre stage in the first crucial stage of moral development, that is, help an infant develop the seeds from which compassion will grow. Later on, mothers, fathers and teachers, are said to hold in their hands the future welfare of the next generation. ${ }^{26}$ One could even go so far as to say that on her model, caring is a sort of political participation, and hence, a duty for republican citizens, in the sense that in order to earn their title of citizens, they must partake in it, either directly or in a supportive role, for without it, the republican society cannot survive. But perhaps one ought to be suspicious of a proposal which makes the flourishing of society depend on women performing a job that is paid little or not at all and leaves no time for participating. This is the conundrum that Iris Marion Young pointed out in her critique of the liberal value of independence when she said that women could not both spend the requisite amount of time nurturing independence in their children while modeling it at the same time if they performing that job without financial and social rewards. She describes the norm of independence as 'male biased and operative in relegating dependent people and their usually female caretakers to an inferior status.' (Young 1995: 536). In Young's article, independence is understood as having a 'well paid secure job' and being in a position to support oneself and one's families. A woman who has to stay home to look after babies, disabled, sick or elderly relatives is obviously not in a position to get such a job. On the other hand, were the state to recognize that caring is a full-time job and a valuable contribution to society, then carers may receive an income for their activities, which would mean they could be described as having a well paid, secure job. The same cannot be said of republican values: care workers, whether or not they have an income, have no time to spare for politics - the nature of caring being such that it does not include time off-and therefore tend to find themselves alienated from the public space, and political participation.

Women in the eighteenth century, whether mothers, or wet-nurses, certainly did not occupy a central place in the running of society, and no real attempt was made at making it so. But this does not mean that De Grouchy's proposal does not point in the direction of reforms that would enable the empowerment of care workers. In this final section, I want to lay out the kind of reforms that is suggested by her proposal.

\footnotetext{
${ }^{25}$ De Grouchy has very little to say about gender directly in the Letters on Sympathy. In the seventh letter she quotes a passage from one of her husband's academy of science speeches, in which he describes the life and achievements of a British surgeon, and says in passing: "the faults of women are the work of men, just as the vices of a people are the crimes of their tyrant". Condorcet himself was a militant feminist, arguing in the national assembly for women's equal rights, and helping Etta Palm d'Aelders publish on the same matter. Perhaps De Grouchy is simply relying on his previously argued viewed. In private correspondence with Etienne Dumont, a few months before writing the Letters, she comments on a book that he has sent her that she is 'dreaming about the manner of bringing up a reasonable woman to live alongside men who will not be so with respect to women for a long time yet.' (my translation) It seems that her preoccupations were not unlike Wollstonecraft's in that respect.

26 "Fathers, mothers, teachers, you have virtually in your hands alone the destiny of the next generation! Ah! How guilty you are if you allow to wither away in your children these precious seeds of sensibility that need nothing more to develop than the sight of suffering, the example of compassion, tears of recognition, and an enlightened hand that warms and coddles them!" 112.
} 
One reason why women are traditionally associated with care, is that they are the first carers for those who have not yet learned to care for themselves. A newborn without a mother, or a female substitute would have been unlikely to survive in the Eighteenth century. Yet, throughout Europe, the common practice was not for mothers to feed their own children but to employ wet-nurses, that is, women who had children of their own, and produced enough milk to feed another at the same time. Wet-nursing was not, as it was portrayed by its detractors, the privilege of the idle rich, of aristocratic women who did not want to make the effort to raise their own child, or to risk spoiling their looks by doing so, but common practice among the urban poor, working women who could not afford to keep infants at home. ${ }^{27}$ But for enlightenment philosophers, wet-nursing was a crime committed by aristocratic women towards their children, out of laziness. Rousseau dedicates the first chapter of his treatise on education Emile to this very question. In a footnote he tells us that "The earliest education is the most important and it undoubtedly is woman's work. If the author of nature had meant to assign it to men he would have given them milk to feed the child." (1992, Book $1, \mathrm{fn} 1)$. He goes on to argue that it is best that the child not be farmed out to a stranger, as there will be no one to ensure that the child is brought up in a healthy manner and one that does not endanger his moral development (I say 'his' because Rousseau is concerned here entirely with the education of men). On the other hand, because mothers are often unwilling to breastfeed their children, it may be best to choose a wet-nurse carefully, and supervise her habits and diets closely. ${ }^{28}$ This is the solution he settles on for Emile, in the story. On the other hand, even if we do choose a 'healthy nurse rather than a petted mother' we still run the risk of psychologically corrupting the child. A child who is suckled by a nurse will develop affections for someone he is taught to look down on, while respecting a mother he has no affection for. The child develops ingratitude.

Wollstonecraft's own argument in favor of mother breastfeeding their own children is not dissimilar. For her, morality begins at home, and a child who is sent out to a wet-nurse will not learn what it is to be loved and to love in return.

Her parental affection, indeed, can scarcely deserve the name, when it does not lead her to suckle her children, because the discharge of this duty is equally calculated to to inspire maternal and filial affection: and it is the indispensable duty of men and women to fulfill the duties which give birth to affections that are the surest preservative against vice. Natural affection, as it is termed, I believe to be a very faint tie, affections must grow out of the habitual exercise of a mutual sympathy; and what sympathy does a mother exercise who sends her babe to a nurse, and only takes it from a nurse to send to school? (234)

One might question why Wollstonecraft does not consider a nurse's affections to be as effective in instilling virtue as a mothers. But she specifies that children are only with their nurse for the first few years, and then, if they are girls, left to fend for themselves in the company of servants, and if they are boys, sent out to school. There is thus no continuity in their affective lives, no chance to develop lasting relationships even if they were lucky enough to be given to a nurse who cared for them.

Of course, whether or not they claim that women should be full citizens, those who argue that mothers must feed their own children do thereby put certain obstacles in women's political advancement. ${ }^{29}$ Even Licia Ronzulli did not bring her daughter to work every day — and yet, the

\footnotetext{
${ }^{27}$ See Jacobus (1992) for a discussion of the practice of wet-nursing in 18th century urban France.

${ }^{28}$ Rousseau (1992) “There can be no doubt about a wife's duty, but considering the contempt in which it is held, it is doubtful whether it is not just as good for the child to be suckled by a stranger." 11 .

${ }^{29}$ Interestingly, the question of whether or not women should nurse their own children did not help settle one way or the other the question of whether women should participate in politics. For some, such as Rousseau, women's nature as feeders did preclude their participation. But for others, such as Wollstonecraft (227), and Pierre Roussel, author of Systeme Physique et Moral de la Femme (1775), women could only accede to political rights if they performed their duties as mothers, including breastfeeding!
} 
child must somehow have been fed and looked after everyday! De Grouchy's letters offer a different solution to revolutionary French mothers. First and foremost, de Grouchy, unlike Rousseau or Wollstonecraft, does not insist that mothers should nurse their own children. This is a direct consequence of her looking for the physiological origins of sympathy. There is nothing physiologically special about a mother except that she produces milk, and has a warm body to cuddle a baby with. If another person can be found who has those same qualities, then there is no reason, on de Grouchy's account, why that person should not nurse a child. Unlike Wollstonecraft and Rousseau, De Grouchy does not systematically dismiss wet-nurses as unhealthy or corrupt. Perhaps paying a nurse a decent wage, and treating her as a family member, rather than a servant, would have helped! But this is not, of itself, a solution to the systematic relegating of women to the kind of support work that leaves little room or opportunity for participation. Historically, wet-nurses were lower class women, so if their existence freed other women for activities which potentially could help them become citizens, it did nothing for women in general.

One tentative reply may draw on the fact that if children develop the right kind of relationships with their nurses, they will have the right kind of moral attitude towards them and will do their best to treat them with fairness and kindness later in life. But this does not solve the problem that careworkers, while they are working, have little time or opportunity for participation. De Grouchy took care of her own nurse when she was too old to work, but this could not make up for lost opportunities to (try and) become a citizen.

A better solution begins with the thought that de Grouchy, by insisting that wet-nurses can be responsible for a child's early moral development, demystifies motherhood. If an eighteenth century mother can only be replaced by another, lactating, woman, the same is no longer true. Bottle feeding and expressing milk mean that men too can nurse infants, providing them with the same physical closeness and the same milk as women can. This means that we have a lot more flexibility for redistributing the work of caring for infants. Two potential applications are: (1) the availability of work-place nurseries staffed by men and women who receive fair financial and social compensations for their work, and (2) an equally distributed parental leave, built on the expectation that fathers and mothers will take equal time off work to perform the work of caring for infants. ${ }^{30}$ Under such conditions, it is possible to recognize the work of caring for infants as essential to the flourishing of society and not, at the same time, turn it into a means of oppressing women and/or lower class people.

What we learn from putting together care and republicanism, following de Grouchy's model, is that a starting at home kind of Republicanism, one that takes family based activities as essential to human lives so that the family has at much importance as the city in defining humanity, is that some of the burdens of care that women typically end up with can and should be redistributed in such a way that all have an equal chance at participating in public life, and an equal understanding of what is involved in family life. But redistributing the burden of care still leaves some individuals in charge of infants, the sick, or the elderly, and these people will, for a time at least, be cut off from participation. So what this model cannot give us is the Aristotelian ideal in which all citizens participate fully in politics. If all we do is ensure that men, as well as women are carers, we do nothing towards increasing overall participation, except perhaps in the sense that no one will feel alienated simply because they are women. But provided the job of caring is shared fairly, throughout society, without anyone feeling they are doing more of their fair share, or having to do it simply because of who they are - a woman, a person of lower economic status or belonging to a particular ethnic group.

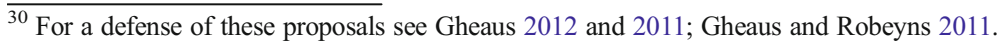




\section{Conclusion}

Republican ideals, from Aristotle to the eighteenth century, have often been built on an invisible form of domination, a support system of non-citizens whose work makes it possible for citizens to participate in public life. This goes against the very idea of republicanism, at least when it is understood as non-domination. In the eighteenth century, Mary Wollstonecraft attempted to show that unless women too became citizens, they were part of that dominated support system. She did not, however, provide much in the way of substitution for the work that women did. It is by following Sophie de Grouchy's model, and putting it together with Nodding's version of care ethics, that we can begin to see a solution. Rather than ignore the work that is being done by women, and carrying on doing political philosophy at public domain level only, we might start with the home, and with the work of educating children to become good citizens. Carers then, can be seen as the source of public life, rather than a necessary background, and their work can be shared among citizens, and not reserved for a class of non-citizens. This is a different solution from the voluntary shared-care solution discussed in the first section of this paper. Caring, in the republican model, is represented as a duty of citizens, not merely as the best or most ethical choice for adults who have children together. Caring is a duty on a par with any other political duty, and it is a form of participation, just as voting, or standing for parliament are. This does entail that there is a need, within a well-functioning society, to embrace measures that facilitate the sharing out of care activities, and that value such activities and those that engage in them. In other words, a good republic will organize care in the same way as it organizes education: to become a citizen, will, in part, mean to become a carer.

\section{References}

Berges S (2013) Wollstonecraft's a vindication of the rights of woman. Routledge, London

Brown K, McClellan J III (2008) Letters on sympathy (1798) A critical edition. Trans Am Philos Soc New Ser 98:4

Costa V (2012) Is Neo-republicanism bad for women? Hypatia 28(4):921-936

Dawson D (1991) Is sympathy so surprising? Adam Smith and French Fictions of Sympathy. Sociability Soc Eighteenth-Century Scotland, Eighteenth-Century Life 15(ns. 1\&2):147-162

Gheaus A (2011) Arguments for non-parental care for children. Soc Theory Pract 37(3):483-509

Gheaus A (2012) Is the family uniquely valuable? Ethics Soc Policy 6(2):120-131

Gheaus A, Robeyns I (2011) Equality-promoting parental leave. J Soc Philos 42(2):173-191

Hausmann R, Tyson LD, Zahidi S (2012) The global gender gap report 2012, world economic forum. http://www.weforum.org/reports/global-gender-gap-report-2012. Accessed 18 Mar 2014

Holtzman E, Williams S (1987) Women in the political wolrd: observations. Deadalus 116(4):2533

Jacobus M (1992) Incorruptible milk: breastfeeding and the French revolution. In: Melzer SE, Rabine LW (eds) Rebel daughters women and the French revolution. OUP, New York

Noddings N (2002) Starting at home. University of California Press, Berkeley

Nussbaum M (1996) Compassion: the basic social emotion. Soc Philos Policy Found 13:27-58

Okin SM (1989) Justice, gender and the family. Basic Books, New York

Pateman C (2007) Why republicanism? Basic Income Stud 2:2

Paxton M, Figdor C, Tiberius V (2012) Quantifying the gender gap: an empirical study of the underrepresentation of women in philosophy. Hypatia 27:4

Philips A (2000) Feminism and republicanism: is this a plausible alliance? J Polit Philos 8(2):279-293

Rousseau J-J (1992) Emile ou de l'Education. Bordas, Paris

Roussel P (1775) Système Physique et Moral de la Femme. Vincent, Imprimeur, Paris 
Ruddick S (1989) Maternal thinking. Beacon, Boston

Slote M (2011) The impossibility of perfection. Aristotle, feminism, and the complexities of ethics. OUP, New York

Van der Dussen S (2012) Political participation of women and motherhood. The case of the Walloon Parliament. Paper given at the European Conference on Politics and Gender, Barcelona, December 2012. http://www. ecpg-barcelona.com/political-participation-women-and-motherhood-case-walloon-parliament. Accessed 24 Sep 2013

Wollstonecraft M (1993) A vindication of the rights of woman. Oxford University Press, Oxford

Young I (1995) Mothers, citizenship, and independence: a critique of pure family values. Ethics 105:535-556 